\title{
Legal Policy of Legislation in the Field of Natural Resources in Indonesia
}

\author{
Herdiansyah Hamzah \\ Faculty of Law, Mulawarman University \\ Jl. Sambaliung No. 1, Samarinda, 75119, East Kalimantan, Indonesia \\ Tel./Fax: +62-541-7774145 E-mail: herdihamzah@gmail.com \\ Submitted: Dec 23, 2015; Reviewed: Feb 4, 2016; Accepted: Feb 11, 2016
}

\begin{abstract}
Given the urgency for the peoples' interests, legislation in the field of natural resources should be treated more compared to other fields. The urgency of arrangement in the field of natural resources is not only the right of every citizen to gain access to natural resources that we have, but also provide a guarantee that Indonesia' natural resources can still be maintained and sustained to future generations. Unfortunately, the legal policy of natural resources tends to move towards free market competition, which is on one side open domination space for both private and foreign sectors, and on the other side attempted to remove the State's role in the control and management of natural resources. This was strengthened by some of legislation in the field of natural resources were canceled in part or in their entirety by the Constitutional Court. In consideration of the Constitutional Court decision, explicitly confirms that the legislation product in the field of natural resources does not comply to the conditionally constitutional, where the right to "the control of state" of natural resources as mandated in Article 33 of the 1945 Constitution, is an absolute and should not be omitted. A shift in the law-political direction that tends to be pro-market, influenced by several aspects: First, the market ideology that is not prevented due to lack of firmness of attitude, principle independence and sovereignty politically by the lawmakers. Second, the inconsistent application of the Indonesia law ideal that embodied in the Pancasila, the 1945 Constitution, in any formulation of laws related to the management of natural resources. Third, still neglecting the peoples' participation, which in the process of making laws relating to the management of natural resources, they are closed to the demands of the people, so it tends to be very elitist and unresponsive to the aspirations of the Indonesian peoples.
\end{abstract}

Keywords: Constitutional Court; Legal Policy; Legislation; Natural Resources

DOI: http://dx.doi.org/10.20956/halrev.v1n1.218

\section{INTRODUCTION}

Speaking about legislaton, of course, cannot be separated from the concept of the rule of law or "rechtstaat". In principle, the concept of rule of law itself is contained in Article 1 paragraph (3) of The 1945 Constitution of the State of the Republic of Indonesia (here- inafter "the 1945 Constitution"), which states that, "The State of Indonesia shall be a constitutional state." According to Asshiddiqie, Indonesia known as the law state (rechtsta-

Article 1 paragraph (3) The 1945 Constitution of the State of the Republic of Indonesia. (Authorized Translation). Jakarta: Depkumham. Downloadable at: http:// goo.g1/MR621e 
at) and not the power state (machtstaat). It contains the terms of the recognition of the principle of law supremacy and constitution, supported the principle of separation and limitation of power as the constitutional system is stipulated in the Constitution, there are guarantees of human rights in the Constitution, the principle of independence of judiciary and not siding that guarantees equality for every citizen in the law, and to guarantee justice for everyone, including the abuse of power by the ruling party. ${ }^{2}$

In essence, the understanding of the law state, the law itself that becomes the deciding everything in accordance with the principle of nomocrasy and the doctrine of "the rule of law, and not of man". Within the framework of "the rule of law", it is believed the recognition that the law has a top position (supremacy of law), the equality in law and government (equality before the law), and it prevail the principle of legality in all its forms in the reality of practice (due process of law). ${ }^{3}$

Basically, the state is constructs created by human beings (human creation) on the pattern of human relations in society are organized in such a manner for the purpose of fulfilling the interests and achieve common goals. ${ }^{4}$ For this reason, the State is given to intervene through law product in the form of legislation. It is intended that in every ac-

\footnotetext{
Jimly Asshiddiqie. (2003). Struktur Ketatanegaraan Indonesia Setelah Perubahan Keempat UU RI Tahun 1945 (A Paper presented on Seminar Pembangunan Hukum Nasional VIII Dengan Tema Penegakan Hukum Dalam Era Pembangunan Berkelanjutan. Organized by Badan Pembinaan Hukum Nasional Departemen Kehakiman dan Hak Asasi Manusia RI, Denpasar, July 1418, 2003), pg. 3-4

Ibid

4 Jimly Asshiddiqie (2010). Pengantar Ilmu Hukum Tata Negara. Jakarta : Rajawali Pers, pg. 11
}

tion taken by the State through the Government, has a legal framework that guarantee the rights of society as has been stated in the constitution.

In the establishment of legislation, the State is required to translate the state fundamental norm, namely Pancasila and the Preamble to the Constitution of the Republic of Indonesia 1945. That is, the legislation produced, must refer to the basic norms of the state. Legislation should lead to the fulfillment of basic rights, particularly in regard to welfare and justice for every citizen without exception. According to Jeremy Bentham, the kindness of public should be the goal of legislator; the benefit of public as basis of its reasoning. Knowing the true good of society is the thing to form of legislation; such understanding is achieved by finding ways to realize such kindness. ${ }^{5}$

Legislation must comply with the general principles or the principle of the establishment of good regulation. Not only on formal aspects or its establishment process, but also on material or norms aspect contained in it. According to Attamimi, ${ }^{6}$ the principles of the establishment of legislation is appropriate, especially in Indonesia, consist of: Indonesian legal ideals; the principle of the State based on the rule of law and by the constitution; and other principles. This is precisely what should be underlying legislation in the field of natural resources in Indonesia. Where the regulations related to the field of natural resources intended to meet

\footnotetext{
Jeremy Bentham. (2010). Teori Perundang-undangan: Prinsip-prinsip Legislasi, Hukum Perdata dan Hukum Pidana. Bandung: Nusamedia, pg. 25

6 Maria Farida Indrati S. (2007). Ilmu Perundang-undangan 2 (Proses dan Teknik Pembentukannya). Yogyakarta : Kanisius, pg. 228
} 
the State's obligation to ensure the welfare and prosperity of the people as much as possible. This is in accordance with the mandate of the 1945 Constitution, Article 33 paragraph (3) which states that, "Soil and water and natural wealth contained therein shall be controlled by the state and used for the welfare of the people to the utmost."

The legislation in natural resources should be treated better than other field, given the urgency for the public interest. The urgency of legislation in the field of natural resources is not only the right of every citizen to gain access to natural resources that we have, but also provide a guarantee that Indonesia's natural resources can still be maintained and sustained to future generations. For it to be an anomaly when many legal products with natural resources that was canceled (in part or in whole as a norm) by the Constitutional Court. Among these regulations, among others, Act No. 7 of 2004 concerning Water Resources Management, Act No. 22 of 2001 concerning Oil and Gas, and Act No. 20 of 2002 concerning Electricity. Some legal product in the form of legislation that was canceled (in part or in whole) by the Constitutional Court, giving facts about face legal products especially in the field of Indonesia's natural resources.

Various questions arise and related to whether those problems related to the perspective of the lawmakers? Given is a fatal thing when legislation product in the public interest (natural resources), it was instead canceled by the Constitutional Court. Or maybe the testing system (review) which is not adequate in every process of establishing legislation, which led to the cancellation?
However, irrespective to the quality of the perspective of legislator and review systems are not adequate, the real key question is how the political direction of the laws of natural resources in Indonesia during this? At first glance if see the reasons for the cancellation of some legislation product by the Constitutional Court, it can be found the initial arguments to the political direction of the laws of the natural resources in Indonesia; First, there is a tendency law-politics that led to the liberalization of the natural resources assets. It is strongly associated with the influence of the free market that in fact wanted to build a new world of economy without territorial limits. Second, the consequences of this free market, establishing the fact that there is an attempt to separate the role of the State in its function as a convidential of managing and distribute the natural resources asset fairly and equitably to all the people of Indonesia. Third, inconsistency use of state fundamental norms, the Pancasila and the Constitution of the Republic of Indonesia of 1945 , as an absolute reference in any preparation of legislation products, particularly in the field of natural resources.

Hence, this article will be directed to develop an analysis the manifestation of law-political in the field of natural resources in Indonesia, as well as provide answers to how the actuality of the law-political in the field of natural resources in accordance with the constitutional mandate that is based on the ideology of Pancasila. Based on this, then this article will focus the discussion on two issues. First, how the reality of lawpolitical in the field of natural resources in Indonesia today? Second, what aspects that 
influence the legal policy in the field of natural resources in Indonesia?

\section{ANALYSIS AND DISCUSSION}

Legal Policy of Legislation in the Field of Natural Resources

Actually, legal policy implies goals and ideals to be achieved. Syaukani and Thohari, ${ }^{7}$ explained that, etymologically, the term of "Politik Hukum" is a Indonesian translation of the legal term of Dutch is "rechtspolitiek", which is formed of two words recht and politiek. Wahjono in Syaukani and Thohari, ${ }^{8}$ giving the definition of politik hukum as a basic policy that determine a direction, form and content of the law to be formed. Satjipto Rahardjo, ${ }^{9}$ defines legal policy as an activity to select and how that would be used to achieve a social objective and specific law in society. If viewed from the background, he is so steeped in law-sociology, then the definition of legal policy which is focused to tend to such sociological, is something which is not surprising.

Further, according to Rahardjo, ${ }^{10}$ there are some fundamental questions that arise in the study of legal policy; First, what goal to be achieved with the existing legal system. Second, what and which ways, that is good to be used to achieve those goals. Third, when the time the law needs to be amended and through the ways how the amendment should be performed. Fourth, can be formulated a standard and well-established pattern, which can help us decide the goal selection process

Syaukani and Thohari. (2008). Dasar-Dasar Politik Hukum. Jakarta : Rajawali Pers, pg. 19

Ibid., pg. 26

Satjipto Rahardjo. (1991). Ilmu Hukum. Bandung : Citra Aditya Bakti, pg. 352

$10 \quad$ Ibid., pg. 352-353 and ways to achieve that goal as well.

Meanwhile, Bellefroid in Latif and Ali, ${ }^{11}$ explained that the legal policy is part of the jurisprudence that examines changes in applicable law that must be done to meet the new demands of public life. If we examine in depth, the true essence of the law-political is the flexibility in the ways and methods of thinking. Where the State is required to constantly adapt to the social circumstances that likely change and certainly it affects the development of the law. Related to this, Utrecht expressed that law-political should define actual laws. Law-political attempt to create rules that will determine how humans should act. Legal policy investigating what changes have to be held in the existing law in order to be in accordance with the social reality (sociale werkelijkheid). ${ }^{12}$ Thus, the legal policy is not only related to the law that will apply in the future (ius constituendum), but also it is much related to what the foundation and the goal of the establishment of law today (ius constitutum).

In Indonesia, the term of "legislation" is defined to everything related to the Act, the intricacies of the Act. Thus, everything related to the Act, includes many aspects, from the system, the process of making, interpretation, review until the enforcement of the norms. This was confirmed by the opinion of SJ Fockema Andreae who argued that "the legislation" which in English is called the legislation, the Dutch language is called by wetgeving, or in German is called with gesetgebung have two different senses; first, the process of state rules establishing,

\footnotetext{
11 Latif and Ali. (2011). Politik Hukum. Jakarta : Sinar Grafika. page. 6

$12 \quad$ Ibid., page. 7
} 
either at central or regional levels. Second, all the rules of the State which is the result of the establishment of regulations, both at the central and regional levels. ${ }^{13}$

Legislation, seen from the terminology, is a translation of wettelijke regeling. The word of Wettelijke means in accordance with a wet or by wet. The word of Wet generally translated by Act and not by legislation. In connection with the basic word of Act, then the translation if wettelijke regeling is legislation. ${ }^{14}$ Legislation is often identified with the written rules. It is derived from the continental European legal system that adheres to the principle of "legism" in the implementation of civil law. That is, if the laws and legislation in terms of its form, is the norm in the form of writing. According to Bagir Manan, the legislation is any written decision is made, ratified and issued by institutions or State officials who have function in accordance with the legislative procedure applicable. ${ }^{15}$

According to Asshiddiqie, one of the main characteristics of the civil law is the importance of the written legislation or "statutory law" or "statutory legislations". The position of "statutory law" takes priority over the decision of the judge or jurisprudence. This differs from the common law system that prioritizes the judge's decision as a reference to the settlement of a

13 Rachmat Trijono (2013). Dasar-Dasar Ilmu Pengetahuan Perundang-Undangan. Depok Timur : Papas Sinar Sinanti, page. 13

14 Yuliandri (2009). Asas-Asas Pembentukan Peraturan Perundang-Undangan Yang Baik: Gagasan Pembentukan Undang-Undang Yang Berkelanjutan. Jakarta : PT. Rajagrafindo Persada, page. 25

15 Bagir Manan (1987). Peranan Peraturan PerundangUndangan dalam Pembinaan Hukum Nasional. Bandung : Armico, pg. 13 case. Therefore, the common law system is also called "the judiciary law" or "the case law". ${ }^{16}$ Further, Asshiddiqie argued that the legal norms that managing (regeling) with the general and abstract norms was included in the written form so-called legislation. Called regulation (regels) because the laws product as result or "outcome" of a series of regulation activities (regeling). ${ }^{17}$ According to Bagir Manan, the man in the street often gives the same sense of legislation, act and law. Often we hear the phrase "it is the law of the State." In fact, what is meant here is to say a local regulation on waste disposal. On the other hand, we are also often hearing "it is clearly the laws of the State". Certainly, referred to the law on elections. ${ }^{18}$

In terms of theoretical concepts, phrases that equate three words actually based on the paradigm of pure legal theory developed by Hans Kelsen and John Austin. ${ }^{19}$ In this legal paradigm mentioned that there is no law beyond act. That law is the order of the ruler who put in the form of legislation. That is, there are differences for three. In the legal system, we know the term of the written law (legislation and act) and the unwritten law. So it is the right thing if we say the act is the law. Another thing, when said act similar to the law. Because the act are part of the law that is written. While, the legislation has a broader scope, where it is one part in it. Likewise, with the term of act with lowercase and uppercase letters that have a differ-

16 Jimly Asshiddiqie (2010). Perihal Undang-Undang. Jakarta: Rajawali Pers, pg. v

Ibid., pg. 14

18 Bagir Manan (1992). Dasar-Dasar Perundang-undangan Indonesia. Jakarta : Ind-Hil, Co, pg.1

19 B. Hestu Cipto Handoyo (2014). Prinsip-Prinsip Legal Drafting \& Desain Naskah Akademik. Yogyakarta : Cahaya Atma Pustaka, pg. 1 
ent understanding. Asshiddiqie, usually use an uppercase letter " $A c t$ " is understood in the sense of the name or act designation that is already certain (definite). In other words, "act" is a genus, while the "Act" is a word associated with certain act or associated with a particular name. ${ }^{20}$

The two previous terminologies, that are the legal policy and legislation, it is simply legal policy of legislation can be interpreted as an attempt to explore the understanding of what is the underlying purpose of the establishment of specific legal product. Both legal-product that have been established and that will be created in the future. In essence, the legal policy of legislation is the scientific study of what the underlying the preparation of a legal product, including the efforts to explore whether and how the mindset of the maker of laws (legislation $a c t$ ) in formulating the legal product makes.

The legal policy of legislation in the field of natural resources, is an attempt to understand the direction and purpose of the establishment of legal-product which regulate the norms of natural resource arrangement in Indonesia. In a sense, intend to move to where the management of natural resources in Indonesia, and whether the arrangement of natural resources are implementable been able to ensure the welfare and prosperity of the people as the constitutions' order.

Thus, the main focus of discussion in this section is a legal product in the form of Act that issued by the House of Representatives (DPR) of the Republic of Indonesia, especially as regards the regulation of natural resources. The data obtained from the

20 Jimly Asshiddiqie (2010), Op.Cit., pg. 21 website of the House of Representatives, as from 1999 to 2015, the House has given issued 558 legal-product in the form of Act. ${ }^{21}$ Among these Acts, there is an arrangement that is directly related to the management of natural resources. The Act is an advanced interpretation of the main norms stated in the constitution, the constitution of 1945 , specifically what is contained in Article 33. Therefore, the study of the legal policy in the field of natural resources will be assessed based on the review of some legislation product that sued in the Constitutional Court.

The reality of legal policy of legislation in the field of natural resources can be analyzed of the case of legal-product review in the form of Act in the Constitutional Court. Among these is the judicial review of Act No. 7 of 2004 on Water Resources. On 18 February 2015, Act No. 7 of 2004 on Water Resources has been canceled by the Constitutional Court in Decision No. 85/PUU$\mathrm{X} / 2013 .^{22}$ In the verdict, the Constitutional Court stated that the Act contrary to the 1945 Constitution and does not have binding legal force.

This verdict is the culmination of a previous decision of the Constitutional Court related to the judicial review of Act on Water Resources. Before, the Constitutional Court has issued a verdict, i.e a case No. 058-059060-063/PUU-II/2004, and No. 008/PUUIII/2005. ${ }^{23}$ The process of judicial review

${ }^{21}$ Quoted on website DPR-RI: http://www.dpr.go.id/uu. Diakses 18 Oktober 2015]

22 Quoted on website The Constitutional Court of the Republic of Indonesia Mahkamah Konstitusi Republik Indonesia: http://www.mahkamahkonstitusi.go.id/ putusan/putusan sidang_2131_85 PUU 2013-UU SumberDayaAir-Dikabulkan-telahucap-18Feb2015-FINAL-\%20wmActionWiz.pdf. Accessed on 19 October 2015

23 Quoted on website the Constitutional Court of RI: 
that carried out repeatedly, indicating that there are problems in the aspect of the conditionally constitutional, the enforcement of a legislation-product. And the condition of constitutionality of legislation-products of water resources management should refer to aspects of the control of the State as defined in Article 33 of the 1945 Constitution.

In consideration of the Constitutional Courts' verdict No. 85/PUU-XI/2013, stated that the condition of constitutionality in question is that the Act on Water Resources in the implementation must ensure the realization of the constitutional mandate of the States' control for water. The rights of States' control for water it can be said to exist where the State, which by the 1945 Constitution was mandated to formulate policies (beleid), still holds the control in perform administrative acts (bestuursdaad), regulatoryaction(regelendaad), management action (beheersdaad), as well as surveillance action (toezichthoudensdaad). ${ }^{24}$

In principle, the constitutional rights must be understood as the rights of States' control for water resources, is ordained as a condition that should not be eliminated in any concession. Regarding the rights of States' control has been described in the judgment of the Constitutional Court No. 85/ PUU-XI/2013, as follows:

“... as one important element in human life that dominates the life of many, water should be controlled by the State (vide Article 33 paragraph (2) and (3) of the Constitution 1945). Based on these considerations, the water management must be severe

http://www.mahkamahkonstitusi.go.id/ putusan/PutusanSDA060.pdf. Accessed on 19 October 2015

24 Verdict of the Constitutional Court No. 85/PUU$\mathrm{XI} / 2013$, page. 140 restrictions as an effort to preserve and continuous availability of water for the life of the nation (vide Article 33 paragraph (4) of the Constitution 1945).".25

Further, in consideration of the Constitutional Court's verdict, its explained the restrictions in question, i.e. First, each water management should not interfere, override, let alone negate the people's right to water as earth and water and natural resources contained in it other than to be controlled by the State, as well as its designation is for the greater prosperity of the people.

Second, that the State should meet the people's right to water. As considered above, access to water is one of the human rights of its own then the Article 28 paragraph (4) determine, "the protection, promotion, enforcement and fulfillment of human rights is the responsibility of the State, especially the Government."

Third, it must be given the life of environmental sustainability, because as one of human rights. Article $28 \mathrm{H}$ paragraph (1) the Constitution 1945 state, "everyone has the right to live physical and spiritual prosperity, reside and earn a good living environment and healthy and receive medical care."

Fourth, that a branch of vital production and dominate the life people who should be controlled by the State (vide Article 33 paragraph (2) of the Constitution 1945) and water in accordance with Article 33 paragraph (3) of the Constitution 1945 should be controlled by the State and used for public welfare, the supervision and control by the State over the water in nature absolute.

$\overline{25 \quad \text { Ibid., pages. } 137-138}$ 
Fifth, as a continuation of the rights of States' control and because water is something very dominate the life of people then the main priority to be given to the water management is State Owned Enterprises or Regional-Owned Enterprises. If all of these restrictions are met and there is still water availability, the Government is still possible to give permission to the private sector to make concessions on the water with certain conditions and tight. ${ }^{26}$

In addition to a judicial review of Act No. 7 of 2004 on Water Resources, the judicial review of Act No. 20 of 2002 on Electricity, is also a reflection of how the reality of legal policy of legislation in the field of natural resources in Indonesia. On 15 December 2004, the Constitutional Court in a decision on the case No. 001-021-022/PUUI/2003, has canceled Act No. 20 of 2002 on Electricity. This decision later became the basis of the establishment of new legal products i.e Act No. 30 of 2009 on Electricity and valid until now.

The consideration of the Constitutional Court in this decision states that electricity is a branch of production for the state and dominate the life of the people, and therefore, according to Article 33 paragraph (2) the Constitution 1945 must be controlled by the State, in the sense that should be managed by the State through the State Enterprises and funded by the government. ${ }^{27}$ It is further mentioned that the meaning of "state controlled" that the production branch that has been owned by the State, then the State must strengthen the position of the enter-

\footnotetext{
$26 \quad$ Ibid., pages. 138-139

27 Verdict of the Constitutional Court No. 001-021-022/ PUU-I/2003, page. 348
}

prises to then gradually can supply their own needs which is the livelihood of many people. ${ }^{28}$ Then, what happens on the contrary, the Act is actually impressed to release the role of the State and entered into the mechanism of market competition through unbundling system and intense competition. It is expressly contrary to the spirit of Article 33 paragraph (2) the 1945 Constitution which is the basic norms of independence of the Indonesian economy.

Other Act that can be used as a comparison of how the manifestation of lawpolitics the legislation in the field of natural resources, is the judicial review of Act No. 22 of 2001 on Oil and Gas. The Constitutional Court has three times ruled decision to the effort of the judicial review. Many norms in the Act that was revised even canceled by the Constitutional Court. The Constitutional Courts'verdict, i.e No. 002/PUU-I/2003, No. 20/PUU-V/2007 and No. 36/PUU-X/2012. On 21 December 2004, through Decision No. 002/PUU-I/2003, the Constitutional Court states that Article 28 paragraph (2) and (3) of Act No.22 of 2001 on Oil and Gas, which handed the determination of the price of fuel and gas by competition mechanism, contrary to the 1945 Constitution.

The Constitutional Court argued that government intervention in pricing policies should be prioritized authority for the production of an important branch and/or dominate the life of many people. ${ }^{29}$ Furthermore, according to the Constitutional Court, should the price of fuel and natural gas domestically is determined by the Government

\footnotetext{
28 Ibid

29 Verdict of the Constitutional Court No. 002/PUUI/2003, hlm. 227
} 
with regard to the interests of certain social groups and consider the mechanism of fair competition and reasonable. ${ }^{30}$

Further, the Constitutional Court's decision strengthens the directions of law-politics in the Act that tend to be oriented to the market and competition. The role of the State in this regard as evidenced trying removed from any norm of law cancelled by the Constitutional Court. Indirectly, the lawmakers have violated the constitution order, that is the 1945 Constitution. Explicitly, there are at least two (2) strong reasons the cancellation of some legislation in the field of natural resources. First, non-fulfillment of conditionally constitutional. That is, Act that are reviewed, both in norm or hierarchy of legislation, contrary to the constitution, the 1945 Constitution. Second, the loss of States' control in the field of natural resources. In the context of law-politics, drafting legislation in the field of natural resources, in fact not based on the goals and ideals of the constitution to be achieved, particularly Article 33 which significantly mandated responsibility on the State through the Government.

\section{Aspects that Affect Legal Policy of Legis- lation in the Field of Natural Resources Market Ideology}

Free-market mechanism seeks to integrate the management of our natural resources into the international economic system, thus making our natural resource management patterns no longer have a boundary. If viewed from the concept of self-sufficient economy, the free-market mechanism is of course to have violated the principles of

${ }_{30} \quad$ Ibid., page. 228 economic sovereignty that the ideals of our founding fathers. Indonesia's position on the free market, it still leaves a long debate on the various parties.

The debate should be set aside with regard to the ideals of the Founding Parents that symbolized in our constitution. Article 33 (2) of the 1945 constitution states that, "Production branches significant to the state and anything controlling the life of many people shall be controlled by the state." Then, affirmed in Article 33 paragraph (3) which states that, "Soil and water and natural wealth contained therein shall be controlled by the state and used for the welfare of the people to the utmost." The phrase "controlled by the state", confirms that the state has full sovereignty in managing natural resources in Indonesia that designation is for the prosperity and welfare of the Indonesia people. Handed over the management of natural resources to the market mechanisms, as well as mortgaging principles and the mandate contained in Article 33 of the 1945 Constitution.

In principle, management of natural resources cannot deny the development of the global market, but it also does not mean that our country must submit and follow the pattern of free-market competition. But when our country faced in between both of these options, the choice of course must be meted out to the management pattern that affirms our nation's economic independence. Embracing the free market, as well as opening the door wide domination of foreign capital to assets and natural resources of Indonesia. It is feared by our founding fathers. As this extract Sukarno's speech which was read on 
17 August 1963 as follows:

"We are a great nation, we are not a tempe nation, we will not beg, we are not going to beg, especiallyifassistance was characterized embroider on this and that condition! Better eat cassava but independent, rather than eating bestik but slaves. The tradition of the Indonesian nation is not the tradition of tempe. We in ancient era once controlled trade throughout Southeast Asia, ever sailed the seas to trade up to Arabia or Africa or China." 31

This is the main issue that determines the legal policy of legislation in the field of natural resources in Indonesia. If studied carefully, almost all legislation-product in the field of natural resources, moving towards free market competition trend. In the interpretation of ideology, the legislation-product in the field of natural resources, directly or indirectly realized itself as pro-market Act. Does this conflict with the norms contained in the constitution? Of course. There are at least 2 (two) reasons that strengthen this position. Firstly, the legislation in the field of natural resources, tend to separate the role of the State in the management of natural resources. It is inversely proportional to the direction of privatization that is now growing on the management of natural resources in Indonesia. It has indeed proved of some legislation that provides a place for it. Such as Act No. 7 of 2004 on Water Resources. Act that has been canceled by the Constitutional Court through Decision No. 85/PUU$\mathrm{XI} / 2013$, is considered to have eliminated the right of "States' control" to manage and to control water resources in Indonesia, thus limiting the distribution and people's access

31 Soekarno's Speech on the Indonesia's Independence, read on 17 August 1963 to water resources which incidentally controlled by private parties. Secondly, legislation in the field of natural resources, tend to integrate the assets of Indonesia's natural resources (water, electricity, oil, gas, etc.) into a free market world. For example, in Act No. 22 of 2001 on Oil and Gas, which provides opportunities in order to determine the price of fuel should be delivered to the market mechanism and competition. ${ }^{32}$ It is considered contrary to Article 33 paragraph (2) the Constitution of 1945. Even in Decision No. 002/PUU-I/2003, the Constitutional Court argued that government intervention in pricing policies should be prioritized authority for the production of an important branch and/or dominate the life of many people.

\section{Law Ideal}

The formulation of norms in the legislation in the field of natural resources should be based on the source of all sources of law in Indonesia, the Pancasila and the Preamble of the 1945 Constitution. According to Mahfud $\mathrm{MD}$, the Preamble and Articles of the Constitution is a source for all Indonesia's national legal policy.

The affirmation of both as a source of legal policy is based on 2 (two) reasons: First, the Preamble and Articles of the 1945 Constitution contains objectives, basic, law ideals, and norms of the Indonesian state should be footing for the goal of law-politics in Indonesia. Second, the Preamble and Articles of the 1945 Constitution contains typical values derived from the views and culture of Indonesia handed down by ancestors

\footnotetext{
32 See Article 28 paragraph (2) Act No. 22 of 2001 on Oil and Natural Gas, have been cancelled by the Constitutional Court through a decision No. 002/PUU-I/2003
} 
centuries ago. ${ }^{33}$

In principle, the establishment of legislation cannot be separated from the theory of legal norm level (stufentheorie). Hans Kelsen as cited in Maria Farida, ${ }^{34}$ argues that the legal norms are leveling and multilayered in a hierarchy (arrangements), in a sense, a lower norm is prevail, sourced and based on the higher norms, the higher norm is prevail, sourced and based on the higher norms again, and so on until a norm that cannot be pursued further and are hypothetical and fictitious that is Basic Norm (Grundnorm).

The theory of legal norms level (stufentheorie) Hans Kelsen was later developed by his student, Hans Nawiasky with his theory die Theorie der vom stufenordnung rechtsnormen. According to Hans Nawiasky, the legal norm in addition to leveling and multilayered, the legal norms of a country is also grouping consisting of four main groups: Group I, Staatsfundamentalnorm. Group II, Staatsgrundgesetz (basic rules of the State). Group III, Formell Gesetz ("formal" Act) and Group IV, Verordnung \& autonome satzung (implementing and autonomous rules). ${ }^{35}$

In the establishment of legislation, there are general principles that should be adhered to in order to guarantee the quality of the legislation that will be created. According to Attamimi, in the context of the establishment of legislation in Indonesia, the principles of legislation can be structured as follows: First, the Indonesia's law ideal; Sec-

\footnotetext{
33 Moh. Mahfud M.D. (2006). Membangun Politik Hukum, Menegakkan Konstitusi. Jakarta: LP3ES, pg. 23

34 Maria Farida Indrati S. (2007), Ilmu Perundang-Undangan 1 (Jenis, Fungsi dan Materi Muatan). Yogyakarta: Kanisius, pg. 41

35 Ibid., pg. 44-45
}

ond, the principle of the State based on law; Third, the principle of governance based on the constitutional system; and Fourth, other principles. ${ }^{36}$ In detail, Attamimi explained that in the establishment of legislation, in addition to be guided by the principles of the establishment of good legislation (beginselen van behoorlijke wetgeving), it is also need to be based on the principles of common law (algemene rechtsbeginselen), in which consists of the principle of the State based on law (rechstaat), the constitution system-based government and the people sovereignty-based State. ${ }^{37}$

Furthermore, Attamimi also introduce, that in the establishment of legislation, there is at least some guidance that can be developed in order to understand the principles of the establishment of god legislation, i.e: First, the principle of Pancasila as the principles of the common law for legislation. Second, the principles of the State based on law as the principles of law common to legislation. Third, the principles of government based on the constitution as the general principles for the legislation, and the Fourth, the principles for legislation developed by the experts. $^{38}$

The law ideal in question is a goal to be achieved of the highest legal norms of Pancasila and the Preamble of the 1945 Constitution, which is in the conception of Hans Nawiaskys' theory called Staatsfundamentalnorm. This fundamental norm is then translated as a rule of thumb states in the body of the 1945 Constitution or referred to Staatsgrundgesetz. The translation is then

\footnotetext{
Yuliandri (2009). Op.Cit., pg. 115

Ibid

$38 \quad$ Ibid
} 
that underlies the regulation in the field of natural resources in Indonesia, particularly those contained in Article 33, which also serves as law ideals in the economy of Indonesia.

The law ideal is not upheld in legislation in the field of natural resources. It is should be able to bring wealth and prosperity for all the people of Indonesia as a trustee of Pancasila and the Preamble the 1945 Constitution. If we read in detail the considerations in the decision of the Constitutional Court related to the judicial review in the field of natural resources, both Act No. 7 of 2004 on Water Resources Management, Act No. 22 of 2001 on Oil and Gas, as well as Act No. 20 of 2002 on Electricity, then we will find the fact that these Act, deviated from the law ideals that mandated by Pancasila, the body of the constitution of 1945. That is, when the legislation in the field of natural resources is not able to guarantee the prosperity of the people of Indonesia, the actual law ideals are not able translated well in the legislation. This aspect gives a sense of law-politics in the field of natural resources in Indonesia, the law-political and regulations that do not uphold the State fundamental norm, the supreme norm that should be a reference to an absolute for any statute or other law that are below.

\section{People participation}

The concept of participation in the making of legal-product, especially regarding the management of natural resources, tends to be overlooked. So that, legal product that is created does not reflect the interests of the people as a whole. This is called Mahfud
MD in Rachmat Triyono ${ }^{39}$ as a legal product which is conservative/orthodox/elitist, are a legal product that contains more reflect the social vision of the political elite, more reflect the government's desire, positivistinstrumentalist, as a tool implementing the ideology and State program.

Contrary to the law of responsive, orthodox are more closed to the demands of groups and individuals in society. In its making, the role and participation of the community is relatively small. Furthermore, according to Mahfud MD, the characteristics of good legal product, is a legal product which is responsive/populist, which is a legal product that reflects the sense of justice and meet the expectations of society. In the process of making gives a big role and full participation of social groups or individuals in the community. The result is responsive to the demands of social groups or individuals in the community. ${ }^{40}$

To classify legal product which is responsive, it can be viewed from 3 (three) aspects: First, in its making process. The role and participation of the peoples is encouraged broadly, including vulnerable groups that will feel the impact of the application of laws which will be determined later. Second, the function and its legal characteristic. Where laws are created, reflecting the aspirations and wishes of the peoples. Not merely wishes of the political elite. Thus, a legal product that is formed is the embodiment of the peoples' wishes. Third, the legal interpretation. Where laws are created, not giving space to a wide interpretation of the

\footnotetext{
39 Rachmat Triyono (2013). Op.Cit., pg. 38
} $40 \quad$ Ibid 
government that will run it. The interpretation is usually sent down through government regulations and other implementing regulations. In essence, without the participation, then the legal policy of natural resources, it will only reflect the interests of the political elite without representation of the peoples' wishes. So, it fair if the legislation in the field of natural resources that do not involve the full participation of the people, will tend to favor the interests of the political elite rather than the people's interests.

\section{CONCLUSION}

The Constitutional Court has canceled (in part or as a whole) legal-product in the field of natural resources. Such as Act No. 22 of 2001 on Oil and Gas, Act No. 20 of 2002 on Electricity, and Act No. 7 of 2004 on Water Resources Management. The cancellation indicates how the realities of legal policy in the field of natural resources in Indonesia. The legal policy of legislation in the field of natural resources tend to move to the principle of natural resource management which is pro-market. This is characterized by the effort to eliminate the role of State on the one side of the controlling of natural resources that includes the earth and water and resource containing it and also the production branch is important and dominate the life of the people to the utmost.

In contrary, on the other hand it opens the natural resources controlling to the private party, and certainly it is dominated by the foreign interest. In the consideration of the Constitutional Court on the judicial review, explicitly affirms that the legislationproduct in the field of natural resources is not fulfill the condition of the constitutional (conditionaly constitutional), in which the implementation must guarantee the realization of constitutional mandate on the right of State's control on the owned natural resources, as mandated in the 1945 Constitutional, particularly containing in Article 33. In this regard, the State must absolutely given the authority to the controlling of natural resources, includes a right to limiting tightly as an effort to preserve and natural resources sustainability for the life of nation.

The legal policy of legislation in the field of natural resources in Indonesia that tends to move toward the free market competition, it is highly influenced by some aspects; First, the absence of attitude firmness, independence of principle and sovereignty politically of the lawmakers to prevent the ideology of market that threatens the goals and ideals the founding of the Indonesian nation, especially in efforts to bring welfare and prosperity as possible for all the people of Indonesia. Second, the implementation is inconsistent of the law ideal of the Indonesia nation as stipulated in the State fundamental norm that is Pancasila and the Preamble of the 1945 Constitution, and its implementation through the basic rules of State (Staatsgrundgesetz) the body of the 1945 Constitution, in any formulation of legislation related to the natural resource management. Third, neglecting people's participation in legislation related to the natural resource management. Legislation in the field of natural resources is still closed to the demands of groups and individuals in society. It can be said that in the making, the role and participation of the peoples is relatively small so it 
tends to be very elitist and conservative and not responsive to the aspirations of the Indonesian peoples.

\section{BIBLIOGRAPHY}

B. Hestu Cipto Handoyo. (2014). PrinsipPrinsip Legal Drafting \& Desain Naskah Akademik. Yogyakarta: Cahaya Atma Pustaka.

Bagir Manan. (1987). Peranan Peraturan Perundang-Undangan dalam Pembinaan Hukum Nasional. Bandung: Armico.

Bagir Manan. (1992). Dasar-dasar Perundang-undangan Indonesia. Jakarta: Ind-Hil, Co.

Jeremy Bentham. (2010). Teori Perundangundangan: Prinsip-prinsip Legislasi, Hukum Perdata dan Hukum Pidana. Bandung: Nusamedia.

Jimly Asshiddiqie. (2003). Struktur Ketatanegaraan Indonesia Setelah Perubahan Keempat UU RI Tahun 1945 (A Paper presented on Seminar Pembangunan Hukum Nasional VIII. Organized by Badan Pembinaan Hukum Nasional Departemen Kehakiman dan Hak Asasi Manusia RI, Denpasar, July 14-18, 2003.

Jimly Asshiddiqie (2010). Pengantar Ilmu Hukum Tata Negara. Jakarta: Rajawali Pers.

Jimly Asshiddiqie (2010). Perihal UndangUndang. Jakarta: Rajawali Pers.

Latif and Ali. (2011). Politik Hukum. Jakarta: Sinar Grafika.
Maria Farida Indrati S. (2007), Ilmu Perundang-Undangan 1 (Jenis, Fungsi dan Materi Muatan). Yogyakarta: Kanisius.

Maria Farida Indrati S. (2007). Ilmu Perundang-undangan 2 (Proses dan Teknik Pembentukannya). Yogyakarta: Kanisius.

Moh. Mahfud M.D. (2006). Membangun Politik Hukum, Menegakkan Konstitusi. Jakarta: LP3ES.

Rachmat Trijono. (2013). Dasar-Dasar Ilmu Pengetahuan Perundang-undangan. Depok: Papas Sinar Sinanti.

Satjipto Rahardjo. (1991). Ilmu Hukum. Bandung: Citra Aditya Bakti.

Syaukani and Thohari. (2008). Dasar-Dasar Politik Hukum. Jakarta: Rajawali Pers.

The 1945 Constitution of the State of the Republic of Indonesia. (Authorized Translation). Jakarta: Depkumham. Downloadable at: http://goo.gl/MR $\underline{621 \mathrm{e}}$

The Constitutional Court of the Republic of Indonesia: http://www.mahkamahkonstitusi.go.id/putusan/putusan_sidang_2131 85 PUU 2013-UU SumberDayaAir-Dikabulkan-telahucap-18Feb2015-FINAL-\%20wmActionWiz.pdf. Accessed on 19 October 2015

Yuliandri. (2009). Asas-Asas Pembentukan Peraturan Perundang-undangan yang Baik: Gagasan Pembentukan UndangUndang yang Berkelanjutan. Jakarta: PT. RajaGrafindo Persada. 